\title{
Reversible phenotype and a lack of direct link to immortalization of Syrian hamster embryonic cells obtained from so-called transformed colonies
}

\author{
Hirohisa Tsuda* \\ Japan Tobacco Inc., Central Pharmaceutical Research Institute \\ 1-1, Murasaki-cho Takatsuki, Osaka 569-1125, Japan
}

\begin{abstract}
Summary
The short-term colony transformation assay employing Syrian hamster embryonic (SHE) cells has been widely used as a simple method for detection of chemical and physical carcinogens. However, little investigation has been done on the biological properties of the early transformed colony (ETC: colony characterized by piling up and criss-cross pattern of growth) itself. This study was performed to examine the properties of these colonies. Secondary or tertiary cultures of SHE cells were treated with benzo $[a]$ pyrene or $N$-methyl- $N$ '-nitro- $N$-nitrosoguanidine. In total, 37 ETCs and 17 normal colonies $(\mathrm{NCs})$ were cloned and analyzed. Obtained results were as follows: (1) Stability of transformed morphology; immediately after cloning, the cells from $3 / 37$ of the ETCs maintained their transformed phenotype, but all cells from other ETCs (34/37) showed flat or well-oriented morphology. Thus, the "transformed" morphology of more than 90\% of the ETCs was reversible. (2) Chromosome abnormality; 3/15 of the clones from ETCs were hypo diploid or tetraploid, while the others (12/15) were normal diploid immediately after cloning. (3) Immortalization; up to about one month after cloning, most of the clones (from transformed or normal colonies) could be subcultured at 1:2 or 1:4 split ratio per week, but thereafter all the clones ceased growing. After about a one month or longer latency, 6/37 of the clones from ETCs and 4/17 of the clones from NCs restarted growing and acquired immortality. That is, there was no significant difference in the frequency of immortalization between ETCs and NCs. Thus, from the present experiment, there was no direct evidence that ETC correlates to acquisition of immortality or tumorigenesis. Further experiments (e.g. comparison of gene expression profiles between cells from transformed and normal colonies using microarray) would be required to give a logical meaning to this short-term transformation assay.
\end{abstract}

Keywords: SHE cell, transformed colony, reversible phenotype, immortalization, tumorigenesis

\section{Introduction}

Since the pioneering work of Berwald and Sachs $(1963,1965)$, the short-term clonal transformation assay employing Syrian hamster embryonic (SHE) cells has been widely used as a simple method for detection of

\footnotetext{
*E-mail: ftsuda@mvb.biglobe.ne.jp Present address: Hatano Research Institute, Food and drug safety center 729-5, Ochiai, Hadano, Kanagawa 257-8523, Japan Received: August 8, 2003, accepted: October 2, 2003

(C) Japanese Environmental Mutagen Society
}

chemical and physical carcinogens, with a high correlation to in vivo carcinogenesis assay in rodents (DiPaolo et al., 1969; Pienta et al.,1977; Barrett et al.,1984; Isfort and LeBoeuf, 1996). The so-called transformed colony (colony characterized by a piling up, criss-cross and random orientation pattern of cell growth) used as an endpoint of this assay has been called customarily "transformed colony" (Berwald and Sachs, 1963), "morphologically transformed colony" (Pienta et al., 1977), and "morphologically altered colony" (Barrett and Ts'o, 1978) or sometimes "malignant transformation" (Borek et al., 1983). Such colonies appear 7 to 10 days after chemical or 
physical carcinogen-treatment of SHE cells inoculated at a small cell number (500 to 10,000 cells per 60 -mm dish). On the other hand, when we treated mass cultures of Syrian hamster embryonic cells $\left(1\right.$ to $10 \times 10^{6}$ cells per 25 $\mathrm{cm}^{2}$ flask or $60 \mathrm{~mm}$ dish) with chemical carcinogen, in most cases, malignant cells (cells which make progressively growing tumors when inoculated in cheek pouches of young adult hamster or in subcutaneous tissue of nude mice) appeared more than 100 days after the chemical treatment (Kuroki and Sato, 1968; Inui et al., 1972; Tsuda et al., 1973). Therefore, it is difficult to believe that the above so-called transformed colony is directly related to malignancy.

We now know that carcinogenesis requires several steps or various gene alterations (Newbold et al., 1982; Newbold and Overell, 1983). Thus it seems important to investigate the true nature of the early transformed colony. Are these colonies composed of cells with temporal morphological changes after carcinogen treatment, are the cells really pre-malignant, does the "transformation" link directly with escape from senescence? Little attempt has been devoted to clarify these questions, although many data including ours (Tsuda et al., 1976; Tsuda and Kato, 1977) have accumulated using this short-term assay not only in the carcinogen-screening tests but also in the investigations of the relationship between mutation and carcinogenesis (Parodi and Brambilla, 1977; Barrett et al., 1978) and in the field of radiation biology (Borek and Hall, 1973; Borek et al., 1983) .

It would be desirable and timely to clarify the abovementioned issue. One of the most direct methods to investigate this problem would be to isolate individual transformed colonies and to examine their biological properties at an early passage stage. In this study, we isolated 37 transformed colonies and 17 normal colonies, and examined the stability of the transformed morphology (for transformed colonies), aneuploidy and transplantability at early passages. The isolated cells were subjected to continuous cultivation, and the frequency of immortalization in the clones from transformed colonies was examined in comparison with that in the clones from normal colonies.

\section{Materials and Methods}

\section{Cells}

Primary cultures were prepared from the back skin tissue of Syrian hamster embryos (4 to 5 embryos) in the 13 or 14 th day of pregnancy by mincing and trypsinization. Syrian hamsters were from a closed colony of Matsumoto Experimental Animal Lab., Japan. The animals were maintained under controlled conditions of temperature $\left(23 \pm 2{ }^{\circ} \mathrm{C}\right)$, humidity $(55 \pm 10 \%)$ and light (12 h light/ $12 \mathrm{~h}$ dark).

\section{Chemicals}

Benzo $[a]$ pyrene (BP; Tokyo-Kasei, Japan), and $N$ methyl- $N$ '-nitro- $N$-nitrosoguanidine (MNNG; Aldrich, USA) were dissolved in ethanol and were diluted by culture medium immediately before use.

\section{Cell culture}

The medium used was Eagle's minimum essential medium (MEM, Nissui, Japan) supplemented with 20\% heat-inactivated fetal bovine serum (FBS, Gibco, USA) . The primary cultures of Syrian hamster embryonic cells were maintained in $75 \mathrm{~cm}^{2}$ plastic flasks (Falcon, USA) at $37{ }^{\circ} \mathrm{C}$ in a $5 \% \mathrm{CO}_{2}$ incubator. The cells that acquired immortality were cultured in MEM plus 10\% FBS.

\section{Transformation experiment and the isolation of individual colonies}

Primary or secondary cultures of Syrian hamster embryonic cells (SHE cells) were seeded into 60-mm dishes (Nunc, Denmark) at a cell concentration of 2, 5 or $10 \times 10^{3}$ cells. In this transformation experiment, feeder layer was not used; but instead, about one-order higher concentration of SHE cells were seeded per dish. This method allowed formation of 100 to 200 relatively well-isolated colonies (Borek et al.,1983; Tsuda et al.,1976; Tsuda and Kato,1977; Barrett et al.,1978).

Twenty-four hrs later, the medium was changed with fresh medium, and BP (5 or $10 \mu \mathrm{g} / \mathrm{mL})$ or MNNG $(0.2$ or $0.5 \mu \mathrm{g} / \mathrm{mL}$ ) were added. Three or $24 \mathrm{hrs}$ after the treatment, the cells were washed twice with Hanks' balanced salt solution and maintained in normal medium. On the 6 th day after the chemical treatment, the medium was changed with fresh medium. On the 7th day, the cells were observed under a phase contrast microscope, and "transformed" and "normal" colonies were marked with a marker pen from outside of the plastic dishes. The cells were washed with phosphate-buffered saline without $\mathrm{Ca}^{++}, \mathrm{Mg}^{++}$, and then the marked colonies were isolated with trypsin-dipped sterile filter paper tips. The cells from the individual colonies were transferred to $25 \mathrm{~cm}^{2}$ flasks or $60 \mathrm{~mm}$ dishes separately and cultured continuously. Usually, when the cells reached confluency, they were subcultured at a split ratio of 1:2 or 1:4. At the same time, cell number was counted to establish cumulative growth curves.

\section{Visualization of cytoskeleton}

Microfilament cable, so-called stress fiber, which is used as one of the markers for normal fibroblastic cells, was visualized by the method of Mukherjee et al. (1982). Briefly, sparse cultures of hamster cells were immersed in an extraction buffer containing $0.5 \%$ TritonX-100, $1 \mathrm{mM}$ ethyleneglycol-bis- $N, N$ '-tetra acetic acid (EGTA) and $4 \%$ polyethyleneglycol 6000 in PIPES buffer ( $\mathrm{pH}$ 6.8) for 
$30 \mathrm{~min}$ at $37^{\circ} \mathrm{C}$. The cells were then fixed for $15 \mathrm{~min}$ in $3 \%$ glutaraldehyde, stained in a $0.2 \%$ solution of Coomassie Blue and examined under a photomicroscope at a magnification of $\times 400$.

\section{Chromosome preparation}

From several clones of transformed colonies, chromosome preparations were prepared immediately after isolation (the 1st or 2nd subcultures were used for preparation) by the method of Rothfels and Siminovitch (1958).

\section{Colony formation on agar plates}

Five $\mathrm{mL}$ of hot soft agar medium (0.5\% Difco's bacto agar in MEM plus 20\% FBS) was poured into $60 \mathrm{~mm}$ dishes and allowed to gel in a $5 \% \mathrm{CO}_{2}$ incubator at $37^{\circ} \mathrm{C}$. Then $2 \times 10^{3}$ cells suspended in $100 \mu \mathrm{L}$ of culture medium were added onto the soft agar plates and the cell suspensions were well spread. The agar plates were incubated for 3 weeks and were observed under a stereo- or phase contrast-microscope. This agar plate method is simple and can obtain almost the same results as the conventional soft agar method (Kamei, 1982).

\section{Immortality}

Cells that were capable of proliferating to the extent of more than 50 population doublings (PD) were considered to be immortal in this experiment. Each "transformed" or "normal" colony was arbitrarily assumed to be composed of 1000 cells, when it was cloned. Thus it was considered that each clone started at the 10th PD $\left(10^{3} \fallingdotseq\right.$ $\left.2^{10}\right)$.
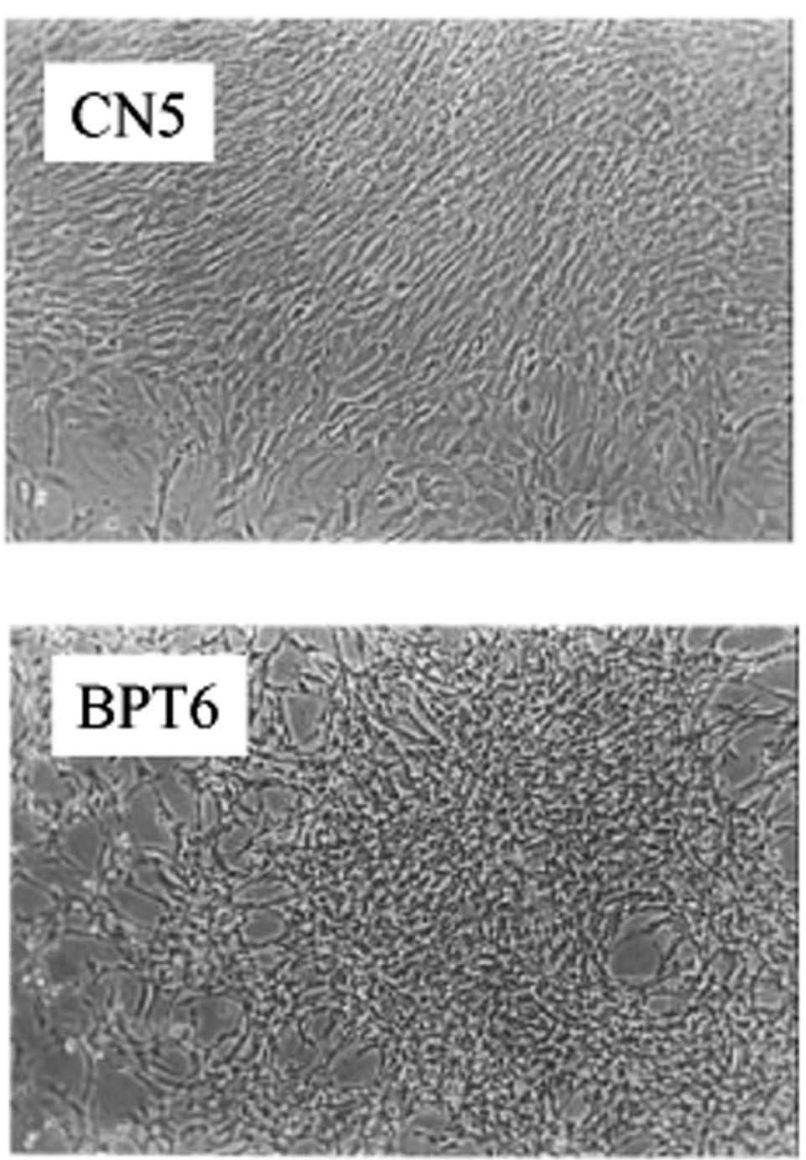

Fig. 1 Morphology of normal and transformed colonies CN5: Normal colony; no treatment in experiment III BPT6: Transformed colony; BP-treatment ( $\mu \mu \mathrm{g} / \mathrm{mL}, 24 \mathrm{hrs}$ ) in experiment III

Table 1 Transformed and normal colonies isolated

\begin{tabular}{|c|c|c|c|c|}
\hline Expt. No. & Treatment* & Morphology $^{* *}$ & $\begin{array}{l}\text { No. of } \\
\text { clones }\end{array}$ & $\begin{array}{c}\text { Name of } \\
\text { clones }\end{array}$ \\
\hline \multirow[t]{4}{*}{ I } & None & $\mathrm{N}$ & 6 & $\mathrm{C} 1$ to $\mathrm{C} 6$ \\
\hline & " & $\mathrm{T}$ & 1 & $\mathrm{C} 7$ \\
\hline & MNNG $(0.5 \mu \mathrm{g} / \mathrm{mL}, 24 \mathrm{~h})$ & $\mathrm{N}$ & 4 & NG5 to NG8 \\
\hline & 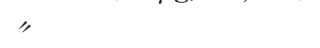 & $\mathrm{T}$ & 4 & NG1 to NG4 \\
\hline \multirow[t]{5}{*}{ II } & None & $\mathrm{N}$ & 1 & $13 \mathrm{C}$ \\
\hline & " & $\mathrm{T}$ & 3 & $10 \mathrm{C}$ to $12 \mathrm{C}$ \\
\hline & $\mathrm{BP}(5 \mu \mathrm{g} / \mathrm{mL}, 3 \mathrm{~h})$ & $\mathrm{T}$ & 3 & $5 \mathrm{BP}$ to $7 \mathrm{BP}$ \\
\hline & " (10 $\mu \mathrm{g} / \mathrm{mL}, 3 \mathrm{~h})$ & $\mathrm{T}$ & 2 & 8BP, 9BP \\
\hline & MNNG $(0.5 \mu \mathrm{g} / \mathrm{mL}, 3 \mathrm{~h})$ & $\mathrm{T}$ & 4 & $1 \mathrm{NG}$ to $4 \mathrm{NG}$ \\
\hline \multirow[t]{6}{*}{ III } & None & $\mathrm{N}$ & 6 & $\mathrm{CN} 1$ to $\mathrm{CN} 6$ \\
\hline & $"$ & $\mathrm{~T}$ & 3 & CT1 to CT3 \\
\hline & $\mathrm{BP}(5 \mu \mathrm{g} / \mathrm{mL}, 24 \mathrm{~h})$ & $\mathrm{T}$ & 6 & ВРТ1, ВРТ3, ВРТ4 \\
\hline & " (10 $\mu \mathrm{g} / \mathrm{mL}, 24 \mathrm{~h})$ & $\mathrm{T}$ & 5 & $\begin{array}{l}\text { ВРT6, ВРT10, BPT11 } \\
\text { BPT2, ВРT5, } \\
\text { BPT7 to ВРT9 }\end{array}$ \\
\hline & MNNG $(0.2 \mu \mathrm{g} / \mathrm{mL}, 24 \mathrm{~h})$ & $\mathrm{T}$ & 2 & NGT2, NGT3 \\
\hline & " $(0.5 \mu \mathrm{g} / \mathrm{mL}, 24 \mathrm{~h})$ & $\mathrm{T}$ & 4 & NGT1, NGT4 to NGT6 \\
\hline
\end{tabular}

* None, no treatment; MNNG, $N$-methyl- $N$ '-nitro- $N$-nitrosoguanidine; BP, benzo $[a]$ pyrene

${ }^{* *} \mathrm{~N}$, normal colony; $\mathrm{T}$, transformed colony 

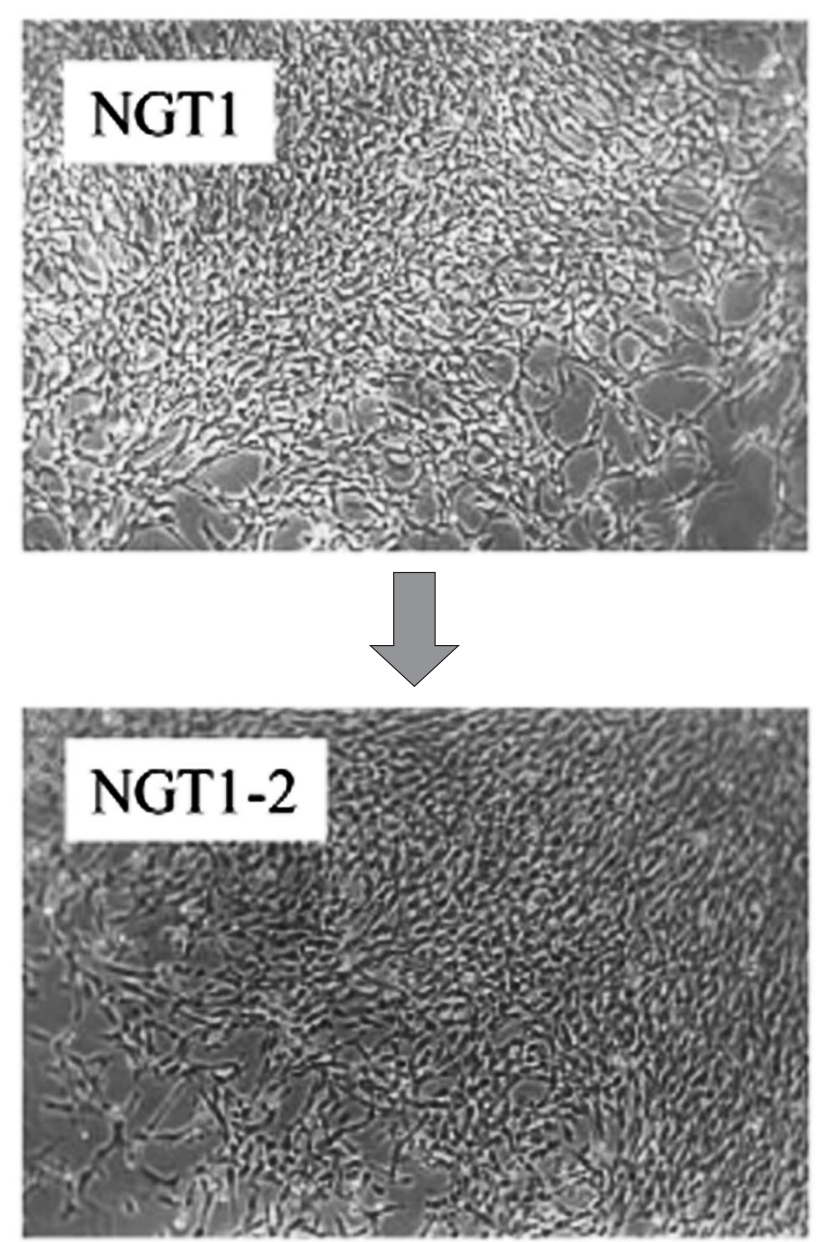

A: Transformed colony which preserved transformed morphology immediately after cloning

NGT1; MNNG-treatment $(0.5 \mu \mathrm{g} / \mathrm{mL}, 24 \mathrm{hrs})$ in experiment III NGT1-2; 5 days after cloning of NGT1
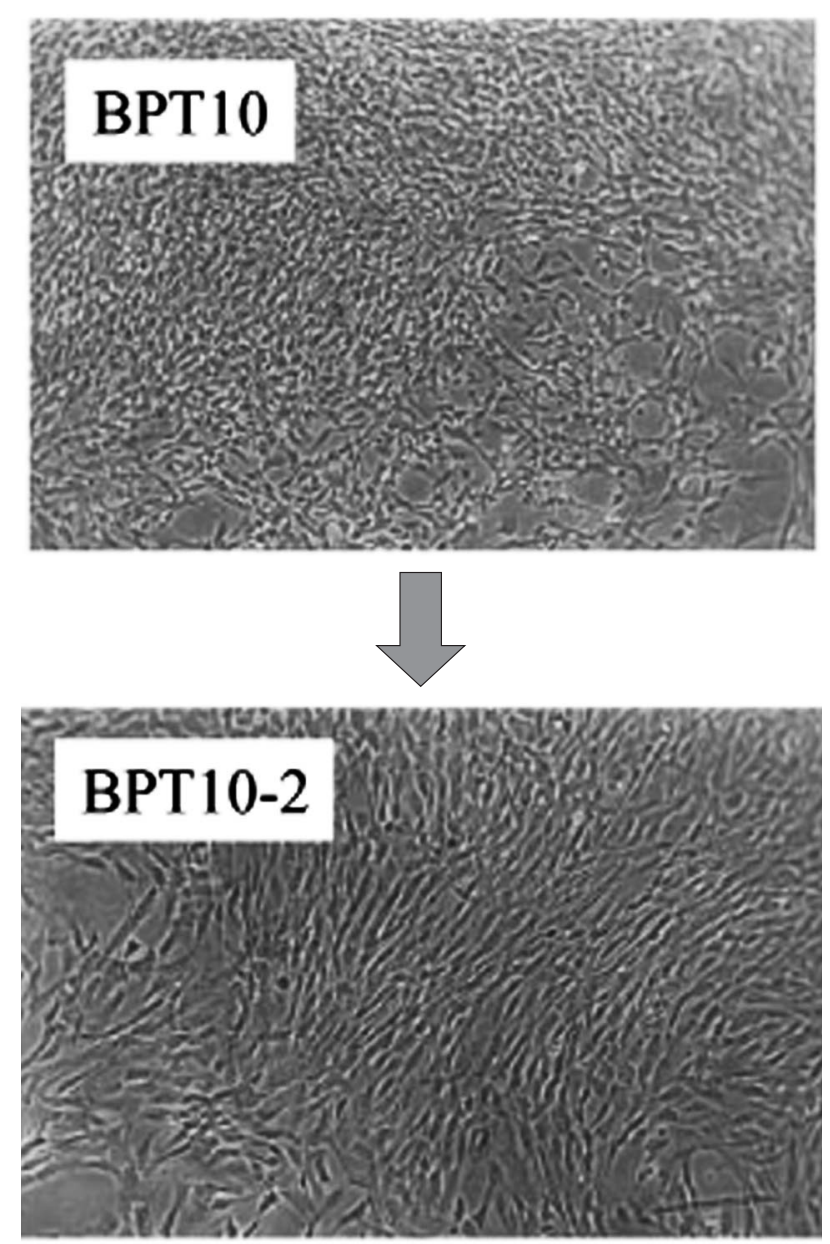

B: Transformed colony which showed well-oriented cell morphology immediately after cloning

BPT10; BP-treatment ( $5 \mu \mathrm{g} / \mathrm{mL}, 24 \mathrm{hrs})$ in experiment III BPT10-2; 7 days after cloning of BPT10

Fig. 2 Stability of transformed morphology

\section{Transplantability test}

Hamster cells ( 1 or $2 \times 10^{6}$ cells/animal) at early stages or after immortalization were suspended in Hanks' salt solution and injected into cheek pouches of young adult hamsters or subcutaneously into nude mice (Balb/c, nu/nu). The animals were observed over a span of more than 3 months to judge tumorigenicity.

\section{Results}

\section{Isolation of normal and transformed colonies}

In this experiment, typically "normal" (well-oriented and smooth colony edge) and "transformed" (crisscross, piled up, irregular colony edge) colonies were isolated from carcinogen-treated and non-treated cultures (Fig. 1). Three separate experiments were carried out, and in total, 37 transformed and 17 normal colonies were isolated. All the colonies isolated are listed in Table 1. Cells were maintained as outlined in Materials and methods for at least 4 months after cloning even when the cells stopped dividing. During the period medium was replaced twice a week.

\section{Stability of transformed morphology}

Whether or not the transformed colonies continued to keep their "transformed morphology" was examined under a phase microscope 5 to 7 days after isolation (Figs. 2A and 2B). The results are summarized in Table 2. Of 37 clones from transformed colonies, only 3 preserved their transformed morphology, and of these, 1 clone (1NG) acquired immortality and later tumorigenicity. The other 2 clones, NGT1 and BPT1, did not obtain immortality and became senescent. However, the 3 clones lost the transformed morphology by the next subculturing. These results showed that the transformed morphology was temporary and reversible.

\section{Chromosome number in transformed colonies}

Chromosome number was examined for 2 normal colonies and 15 transformed colonies 6 to 16 days after the isolation. Results are shown in Table 3 . In experiment 
I, only 1 clone from a transformed colony (NG2) was examined and showed normal diploid. Eventually, this clone obtained immortality. In experiment II, 1 clone from a normal colony (13C) and 3 (11C, $6 \mathrm{BP}$ and $8 \mathrm{BP})$ out of 6 from transformed colonies showed normal diploid. Among the 3 aneuploid clones, 5BP showed tetraploid,

Table 2 Stability of transformed morphology immediately after cloning

\begin{tabular}{cccc}
\hline Expt. No. & $\begin{array}{c}\text { No. of transformed } \\
\text { colonies cloned }\end{array}$ & $\begin{array}{c}\text { No. of clones } \\
\text { with T.M. }\end{array}$ & $\begin{array}{c}\text { Names of clones } \\
\text { with T.M. }\end{array}$ \\
\hline I & 5 & 0 & \\
II & 12 & 1 & 1 NG $^{* *}$ \\
III & 20 & 2 & NGT1, BPT1 \\
\hline
\end{tabular}

*T.M.: Transformed morphology

** This clone acquired immortality after long-term passages.

Table 3 Chromosome number in the cells from transformed colonies immediately after cloning

\begin{tabular}{|c|c|c|c|c|}
\hline $\begin{array}{l}\text { Expt. } \\
\text { No. }\end{array}$ & $\begin{array}{l}\text { Name of } \\
\text { clone }\end{array}$ & $\begin{array}{l}\text { Culture } \\
\text { days }{ }^{*}\end{array}$ & $\begin{array}{c}\text { Modal chromosomal } \\
\text { number }\end{array}$ & $\begin{array}{l}\text { Acquisition of } \\
\text { immortality }^{* * *}\end{array}$ \\
\hline I & NG2 & 11 & 44 & + \\
\hline \multirow[t]{7}{*}{ II } & $13 C^{* *}$ & 11 & 44 & - \\
\hline & $10 \mathrm{C}$ & 11 & 43 & - \\
\hline & $11 \mathrm{C}$ & 6 & 44 & - \\
\hline & $5 \mathrm{BP}$ & 11 & $4 n$ & - \\
\hline & $6 \mathrm{BP}$ & 11 & 44 & - \\
\hline & $8 B P$ & 6 & 44 & - \\
\hline & $1 \mathrm{NG}$ & 14 & 43 & + \\
\hline \multirow[t]{9}{*}{ III } & $\mathrm{CN} 1^{* *}$ & 6 & 44 & + \\
\hline & BPT1 & 12 & 44 & - \\
\hline & BPT2 & 8 & 44 & - \\
\hline & BPT4 & 8 & 44 & - \\
\hline & BPT6 & 16 & 44 & - \\
\hline & ВРТ8 & 11 & 44 & - \\
\hline & BРТ9 & 11 & 44 & + \\
\hline & BPT10 & 11 & 44 & - \\
\hline & BPT11 & 8 & 44 & + \\
\hline
\end{tabular}

* Days after the cloning

** Normal colony

*** Information after long-term passages. See Table 4. but ceased to grow after long-term passages. 10C and $1 \mathrm{NG}$ showed 43 chromosomes, but only the latter acquired immortality. In experiment III, 1 clone from a normal colony and 8 from transformed colonies were examined and all showed normal diploid. The clone (CN1) of a normal colony and 2 clones (BPT9 and BPT11) of transformed colonies subsequently obtained immortality.

In total, chromosome number of cloned cells at the first or second passage was normal diploid in 12 out of 15 clones from transformed colonies, and 2 out of 2 from normal colonies. Thus, the early transformed phenotype seemed not to be directly related to changes in chromosome number.

\section{Acquisition of immortality (escape from senes- cence)}

Consequences of the isolation and continuous cultivation of the cloned cells from normal or transformed colonies are summarized in Table 4 . In total, 4 out of 17 clones from normal colonies $(23.5 \%)$ and 6 out of 37 clones from transformed colonies $(16.2 \%)$ acquired immortality.

Cumulative growth curves of respective clones were generated for several isolated clones. Fig. 3A shows the cumulative growth curves from 2 immortalized clones from experiment I (C3 and NG2). NG2 showed a lag period during days 20 to 60 after cloning, but thereafter regained vigorous growth capacity. In the case of $\mathrm{C} 3$, about 100 days of growth-cessation was observed before growth recommencement (The population doubling of this clone was only about 30 on the 160th day after cloning, but this clone continued to grow thereafter more than 50 population doublings).

Fig. 3B shows the growth curves of several clones from experiment II, in which most clones (including $13 \mathrm{C}$ isolated from a normal colony) maintained their active growth for 3 to 6 passages after cloning. However, all the clones except $1 \mathrm{NG}$ stopped growing and never restarted during 5 months of observation. 1NG was the only clone

Table 4 Immortalized clones after long-term passages

\begin{tabular}{ccccl}
\hline $\begin{array}{c}\text { Expt. } \\
\text { No. }\end{array}$ & $\begin{array}{c}\text { No. of clones } \\
\text { examined }\end{array}$ & $\begin{array}{c}\text { Morphology* } \\
\text { at cloning }\end{array}$ & $\begin{array}{c}\text { No. of clones } \\
\text { immortalized }\end{array}$ & $\begin{array}{c}\text { Names of clones } \\
\text { immortalized }\end{array}$ \\
\hline I & 10 & $\mathrm{~N}$ & 1 & $\mathrm{C} 3$ \\
& 5 & $\mathrm{~T}$ & 1 & NG2 \\
II & 1 & $\mathrm{~N}$ & 0 & \\
& 12 & $\mathrm{~T}$ & 1 & 1NG \\
III & 6 & $\mathrm{~N}$ & 3 & CN1, CN3, CN5 \\
& 20 & $\mathrm{~T}$ & 4 & CT3, NGT2 \\
& & & & BPT9, BPT11 \\
Total & 17 & $\mathrm{~N}$ & 4 & \\
& 37 & $\mathrm{~T}$ & 6 & \\
\hline
\end{tabular}

${ }^{*} \mathrm{~N}$, normal colony; $\mathrm{T}$, transformed colony 

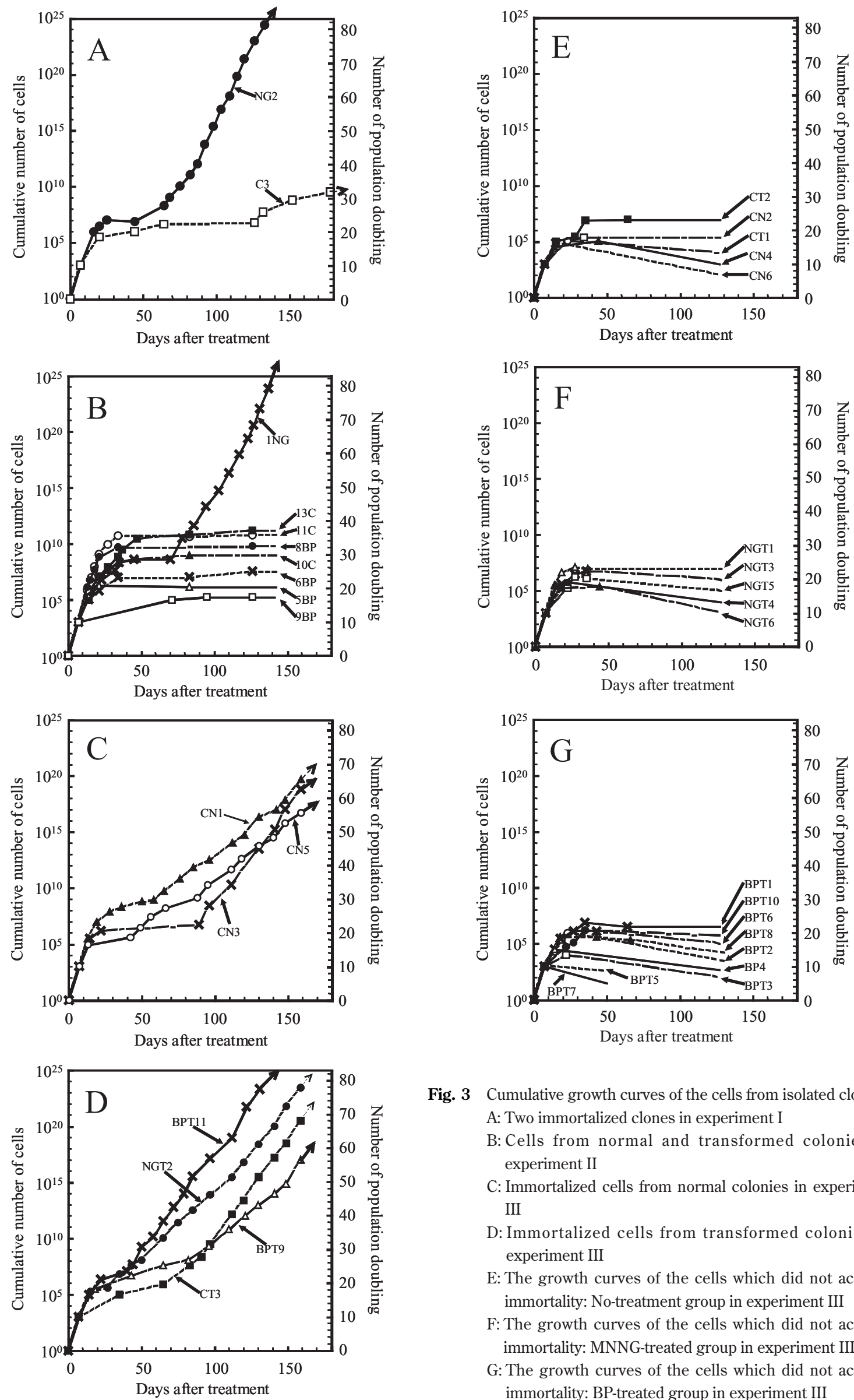

Fig. 3 Cumulative growth curves of the cells from isolated clones A: Two immortalized clones in experiment I

B: Cells from normal and transformed colonies in experiment II

C: Immortalized cells from normal colonies in experiment III

D: Immortalized cells from transformed colonies in experiment III

E: The growth curves of the cells which did not acquire immortality: No-treatment group in experiment III

F: The growth curves of the cells which did not acquire immortality: MNNG-treated group in experiment III

G: The growth curves of the cells which did not acquire immortality: BP-treated group in experiment III 
fulfilling the two conditions (maintained transformed morphology and change in chromosome number immediately after cloning), and attained immortality. However, even this clone had a 30 to 40 day no-growth period before growth recommenced.

Figs. 3C and 3D show the cumulative growth curves of immortalized clones derived from normal and transformed colonies, respectively, in experiment III. Fig. 3C shows growth curves from 3 normal colonies (CN1, CN3 and CN5) which acquired immortality. The growth curves from 4 transformed colonies (CT3, BPT9, BPT11 and NGT2) are presented in Fig. 3D, which demonstrate that the growth-arrest periods were relatively shorter $(20$ to 30 days) in 2 clones (BPT11 and NGT2). In total, 9 out of 10 immortalized clones restarted growth within 100 days after cloning; the one exception was C3 (Fig. 3A).

Figs. $3 \mathrm{E}$ to $3 \mathrm{G}$ present the cumulative growth curves of clones which did not obtain immortality (from experiment III); Fig. 3E displays the growth curves from the no treatment group, and Figs. $3 \mathrm{~F}$ and $3 \mathrm{G}$ show the growth curves from MNNG-treated and BP-treated groups, respectively. Both NGT1 and BPT1, which maintained the transformed morphology immediately after cloning (Table 2), grew rapidly during early passages after cloning, but ceased growing and senesced thereafter.

\section{Stress fiber and colony formation on agar plates}

In experiment III, stress fiber was visualized in the cells cloned from several colonies. Sharp stress fiber is one of the markers for normal fibroblasts. Results are summarized in Table 5. On the 7th day after cloning, cells from 3 normal colonies, which later obtained immortality, had sharp stress fiber. Among the cells from the transformed colonies, BPT1 cells had only weak or no stress fiber, in parallel with the morphology of this clone as a mass. This clone showed transformed morphology immediately after cloning (Table 2). Cells of the remainder of the colonies had relatively sharp stress fiber at the earlier passage stage. These results show that almost all the cells from transformed colonies had sharp stress fiber, a marker for normal fibroblast, immediately after cloning.

For some immortalized clones, the stress fiber was examined after long-term passaging (152 days after cloning). CN5 had sharp stress fiber even after immortalization, and could not form colonies on soft agar plates, whereas the other 3 clones lost stress fiber and could form colonies on soft agar plates.

Transplantability of the cells derived from normal and transformed colonies

Results are summarized in Table 6. From experiment I, transplantability was examined for 2 immortalized clones. C3 cells did not take even after 100 population doublings. NG2 cells, immediately after growth recommencement
(59 culture days), did not take but later acquired transplantability (after more than 110 culture days). From experiment II, transplantability was examined for 3 clones from transformed colonies (11C, 8BP and $1 \mathrm{NG}$ ) at earlier stages after cloning; all 3 were negative. For $1 \mathrm{NG}$ cells, the test was performed also after growth recommencement; cells did not take after 96 days of culture, but later did take after 223 days of culture. From experiment III, transplantability was examined for 6 immortalized clones. Only NGT2 cells took (184 days after cloning); other 5 clones were negative when tested at 184 to 193 days after cloning. Although clones, CN1 and CN3 could form colonies on the soft agar plate (Table 5), they had not transplantability.

\section{Discussion}

The purpose of this study was to investigate the biological properties of early transformed colonies from the Syrian hamster embryonic fibroblast transformation assay. It is reported that this in vitro assay has good correlation with in vivo carcinogenesis tests in rodents. In the present experiments, individual transformed (or normal) colonies were isolated and cultured continuously.

\section{Transformed phenotype}

As shown in Table 2, only 3 colonies out of 37 transformed colonies continued to maintain their transformed morphology immediately after cloning. However, even these 3 clones lost their transformed morphology after the next subculture and showed flat or well-oriented cell morphology. These results clearly show that the transformed phenotype is not a hereditary change in most cases.

\section{Chromosomes}

Chromosome number was examined at early stages after cloning (6 to 14 days). Twelve out of 15 clones from transformed colonies showed normal diploid $(2 \mathrm{n}=44)$. Thus, the transformed phenotype seems not to be directly related to chromosomal numerical changes.

\section{Immortality}

As shown in Figs. 3A to 3G, most of the clones maintained their active growth and could be sub-cultured at $1: 2$ or $1: 4$ split ratio up to 20 to 30 days after cloning. All the clones then ceased growth. After this period of 20 days or more, some clones restored their growth capacity and acquired immortality. Six out of 37 clones from the transformed colonies and 4 out of 17 normal colonies obtained immortality. Therefore, there was no significant difference in the frequency of immortalization between the transformed colonies and the normal colonies. Furthermore, it was apparent that the cells in transformed colonies were not immortalized at least at the stage of cloning ( 7 days after chemical treatment). These results also suggest that 
Table 5 Visualization of stress fiber and colony formation on soft agar plates examined on clones in experiment III

\begin{tabular}{|c|c|c|c|c|c|}
\hline $\begin{array}{l}\text { Name of } \\
\text { clone }\end{array}$ & $\begin{array}{l}\text { No. of } \\
\text { passage }\end{array}$ & $\begin{array}{l}\text { Culture } \\
\text { days* }\end{array}$ & $\begin{array}{l}\text { Stress } \\
\text { fiber** }\end{array}$ & $\begin{array}{l}\text { Colony formation } \\
\text { on agar plate }\end{array}$ & $\begin{array}{l}\text { Acquisition of } \\
\text { immortality }\end{array}$ \\
\hline \multicolumn{6}{|c|}{ Early Passages } \\
\hline $\mathrm{CN} 1$ & 3 & 7 & ++ & & + \\
\hline CN3 & 2 & 7 & ++ & & + \\
\hline CN5 & 2 & 7 & ++ & & + \\
\hline $\mathrm{CT} 1$ & 3 & 7 & ++ & & - \\
\hline СТ2 & 2 & 7 & + & & - \\
\hline BPT1 & 2 & 12 & $-1+$ & & - \\
\hline ВРТ2 & 2 & 12 & + & & - \\
\hline ВРТ9 & 2 & 12 & ++ & & + \\
\hline NGT2 & 2 & 12 & + & & + \\
\hline NGT4 & 2 & 7 & ++ & & - \\
\hline \multicolumn{6}{|c|}{ Late Passages } \\
\hline $\mathrm{CN} 1$ & 17 & 152 & $-/+$ & + & + \\
\hline CN5 & 14 & 152 & ++ & - & + \\
\hline СТ3 & 12 & 152 & $-/+$ & ++ & + \\
\hline NGT2 & 17 & 152 & $-/+$ & ++ & + \\
\hline
\end{tabular}

* Days after cloning

** ++ , sharp stress fiber was observed; + , stress fiber was positive; $-/+$, no

or weak stress fiber was observed.

*** Information after long-term passages. See Table 4.

Table 6 Transplantability of the cells derived from normal and transformed colonies

\begin{tabular}{clccccc}
\hline $\begin{array}{c}\text { Expt. } \\
\text { No. }\end{array}$ & $\begin{array}{c}\text { Name of } \\
\text { clones }\end{array}$ & $\begin{array}{c}\text { Morphology } \\
\text { at cloning }\end{array}$ & $\begin{array}{c}\text { No. of } \\
\text { passage }\end{array}$ & $\begin{array}{c}\text { Culture } \\
\text { days* }\end{array}$ & $\begin{array}{c}\text { No. of } \\
\text { cells }\end{array}$ & $\begin{array}{c}\text { Takes** } \\
\text { (Takes/Animals) }\end{array}$ \\
\hline I & C3 & N & ND*** & $(>1$ year) & $2 \times 10^{6}$ & $-(0 / 2) \#$ \\
& NG2 & T & 6 & 59 & $1 \times 10^{6}$ & $-(0 / 2)$ \\
& " & " & 15 & 110 & $1 \times 10^{6}$ & $+(2 / 2)$ \\
II & " & " & 24 & 163 & $2 \times 10^{6}$ & $+(2 / 2)$ \\
& 11C & T & 2 & 7 & $2 \times 10^{6}$ & $-(0 / 2)$ \\
& 8BP & T & 2 & 7 & $2 \times 10^{6}$ & $-(0 / 2)$ \\
& 1NG & T & 2 & 17 & $1 \times 10^{6}$ & $-(0 / 2)$ \\
& " & " & 10 & 96 & $2 \times 10^{6}$ & $-(0 / 3)$ \\
III & CN1 & N & 29 & 223 & $1 \times 10^{6}$ & $+(2 / 2)$ \\
& CN3 & N & 14 & 184 & $1 \times 10^{6}$ & $-(0 / 2) \#$ \\
& CN5 & N & 17 & 193 & $1 \times 10^{6}$ & $-(0 / 2) \#$ \\
& CT3 & T & 15 & 184 & $1 \times 10^{6}$ & $-(0 / 2) \#$ \\
& BPT11 & T & 21 & 186 & $1 \times 10^{6}$ & $-(0 / 4) \#$ \\
& NGT2 & T & 20 & 184 & $1 \times 10^{6}$ & $+(2 / 4) \#$ \\
\hline
\end{tabular}

* Days after cloning

** Cells were inoculated into cheek pouches of young adult hamsters.

\# Cells were inoculated into subcutaneous tissue in nude mice.

${ }^{* * *}$ No data available

the immortalization of Syrian hamster embryonic cells is not a single step event, confirming the previous report by Bols et al. (1991).

\section{Tumor-formation}

As shown in Table 6, the cells of 3 transformed colonies (11C-2, 8BP-2 and 1NG-2) tested were negative for tumor formation at early passages after cloning, even for $1 \mathrm{NG}$ which was later immortalized after long-term passag- ing. This result is important as it signifies that these transformed colonies at an early passage should not yet be called "malignant".

Transplantability for several immortalized colonies was also examined. A clone, NG2, did not take on the 59th day after cloning (immediately after restart of growth), but did take later on (110th day and 163rd day after cloning) and developed into fibrosarcomas. Similarly, 1NG had no transplantability after restart of growth (96th day), but 
did take later on (223rd day). Thus, these results show that even immortalized SHE cells do not have transplantability at early stages, and further continuous cultivation is required for the acquisition of tumor-formation capability. This notion is consistent with previous reports (Kuroki and Sato, 1968; Barrett and Ts'o, 1978; Barrett, 1980). Comparing the transplantabilty among immortalized clones (Table 6), the following was noted. Three out of 4 clones from carcinogen-treated transformed colonies had transplantability (transplantability positive; NG2, 1NG, NGT2, negative; BPT11), whereas none of 4 clones from non-treated normal colonies had transplantability (negative; C3, CN1, CN3, CN5). Although more additional experiments are required to discuss precisely this issue, the above observation may suggest some link between carcinogen-treatment (or early transformed colony) and transplantability.

Based on the experimental results shown in this paper, the following conclusions could be drawn:

1. The early transformed phenotype (piling up, crisscross and random orientation pattern of cell growth) of the SHE cells is not a stable (inherent) change.

2. Cells from the transformed colonies have not yet acquired an immortal nature at the early stages ( 7 to 8 days after the chemical treatment), and the transformed morphology does not directly correlate to immortalization.

3. The early transformed colonies themselves are not yet malignant.

From the present experiments, evidence suggesting that the early transformed colonies from SHE cells may be a first step to malignant transformation or may link to carcinogenesis, could not be obtained. However, many studies on chemical testing with the SHE cell transformation assay show good correlations with the results of in vivo carcinogenesis tests in rodents. What then do the early transformed colonies represent? In order to answer this, and to make the SHE cell transformation assay more solidly based on scientific understanding, further efforts and ideas are required. For example, chemical carcinogens may temporarily change the expression of some growth factors, oncogenes or anti-oncogenes resulting in the morphological changes. For these studies, exhaustive gene expression analysis using microarray (Bae et al., 2002; Tellgren et al., 2003; Lamb et al., 2003) seems to be useful in the near future, although the number of cDNA clones obtained from Syrian hamster is not enough to apply this analysis at present. It is also an interesting notion that the transformation is the result of a block in the cellular differentiation of stem cells within the SHE cell population, as suggested by Isfort (Isfort, 2000). However, how can a direct link between carcinogen exposure and a block of differentiation be determined? Further studies for the elucidation of these questions are surely required.

\section{Acknowledgements}

The author thanks Prof. Dr. Makoto Umeda (the former President of the Yokohama City University) for critical reading of the manuscript, and Dr. Noriho Tanaka (Cell Toxicology, Hatano Research Institute, Food and Drug Safety Center) and Dr. Makoto Hayashi (National Institute of Health Sciences) for valuable discussions.

\section{References}

Bae, D.S., W.H. Hanneman, R.S. Yang and J.A. Campain (2002) Characterization of gene expression changes associated with MNNG, arsenic, or metal mixture treatment in human keratinocytes: application of cDNA microarray technology, Environ. Health Perspect., 110, suppl. 6, 931-941.

Barrett, J.C., N.E. Bias and P.O.P. Ts'o (1978) A mammalian cellular system for the concomitant study of neoplastic transformation and somatic mutation, Mutat. Res., 50, 121-136.

Barrett, J.C. and P.O.P. Ts'o (1978) Evidence for the progressive nature of neoplastic transformation in vitro, Proc. Natl. Acad. Sci. USA, 75, 3761-3765.

Barrett, J.C. (1980) A preneoplastic stage in the spontaneous neoplastic transformation of Syrian hamster embryo cells in culture, Cancer Res., 40, 91-94.

Barrett, J.C., T.W. Hesterberg and Thomassen, D.G. (1984) Use of cell transformation systems for carcinogenicity testing and mechanistic studies of carcinogenesis, Pharmacol. Rev., 36, 53-70.

Berwald, Y. and L. Sachs (1963) In vitro cell transformation with chemical carcinogens, Nature, 200, 1182-1184.

Berwald, Y. and L. Sachs (1965) In vitro transformation of normal cells to tumor cells by carcinogenic hydrocarbons, J. Natl. Cancer Inst., 35, 641-661.

Bols, B.L.M.C., J.M. Naaktgeboren and J.W.I.M. Simons (1991) Immortalization of Syrian hamster embryo cells is in itself a multistep event, Cancer Res., 51, 1177-1184.

Borek, C. and E. Hall (1973) Transformation of mammalian cells in vitro by low doses of X-rays, Nature, 243, 450-453.

Borek, C., E.J. Hall and M. Zaider (1983) X ray may be twice as potent as $\gamma$ rays for malignant transformation at low doses, Nature, 301, 156-158.

DiPaolo, J.A., P.J. Donovan and R.L. Nelson (1969) Quantitative studies of in vitro transformation by chemical carcinogens, J. Natl. Cancer Inst., 42, 867-874.

Inui, N., S. Takayama and T. Sugimura (1972) Neoplastic transformation and chromosomal aberrations induced by $N$-methyl- $N$ 'nitro- $N$-nitrosoguanidine in hamster lung cells in tissue culture, J. Natl. Cancer Inst., 48, 1409-1417.

Isfort, R.J. and R.A. LeBoeuf (1996) Application of in vitro cell transformation assays to predict the carcinogenic potential of chemicals, Mutat. Res., 365, 161-173.

Isfort, R.J. (2000) Mechanisms of cell transformation in the Syrian hamster embryo (SHE) cell transformation system, Ann. N.Y. Acad. Sci., 919, 86-96.

Kamei, H. (1982) Relationship between anchorage-independent growth and cytochalasin B-induced multinucleation in cloned BHK-21/C13 cells and their chemical transformants, Cell Structure and Function, 7, 61-70.

Kuroki, T. and H. Sato (1968) Transformation and neoplastic development in vitro of hamster embryonic cells by 4-nitroquinoline-1- 
oxide and its derivatives, J. Natl. Cancer Inst., 41, 53-71.

Lamb, J., S. Ramaswamy, H.L. Ford, B. Contreras, R.V. Martinez, F.S. Kittrell, C.A. Zahnow, N. Patterson, T.R. Golub and M.E. Ewen (2003) A mechanism of cyclin D1 action encoded in the patterns of gene expression in human cancer, Cell, 114, 323-334.

Mukherjee, B.B., P.M. Mobry and S.D.J. Pena (1982) Retinoic acid induces anchorage- and density-dependent growth without restoring normal cytoskeleton, EGF binding, fibronectin content and ODC activity in a retrovirus-transformed mouse cell line, Exptl. Cell Res., 138, 95-107.

Newbold, R.F., R.W. Overell and J.R. Connell (1982) Induction of immortality is an early event in malignant transformation of mammalian cells by carcinogens, Nature, 299, 633-635.

Newbold, R.F. and R.W. Overell (1983) Fibroblast immortality is a prerequisite for transformation by EJ c-Ha-ras oncogene, Nature, 304, 648-651.

Parodi, S. and G. Brambilla（1977） Relationships between mutation and transformation frequencies in mammalian cells treated "in vitro" with chemical carcinogens, Mutat. Res., 47, 53-74.

Pienta, R.J., J.A. Poiley and W.B. Lebherz III（1977） Morphological transformation of early passage golden Syrian hamster embryo cells derived from cryopreserved primary cultures as a reliable in vitro bioassay for identifying diverse carcinogens, Int. J. Cancer, 19, 642-655

Rothfels, K.H. and L. Siminovitch (1958) An air-drying technique for flattening chromosomes in mammalian cells grown in vitro, Stain Technol., 33, 73-77.

Tellgren, A., T.J. Wood, A. Flores-Morales, U.E. Torndal, L. Eriksson and G. Norstedt (2003) Differentially expressed transcripts in neoplastic hepatic nodules and neonatal rat liver studied by cDNA microarray analysis, Int. J. Cancer, 104, 131-138.

Tsuda, H, N. Inui and S. Takayama (1973) In vitro transformation of newborn hamster cells by sodium nitrite, Biochem. Biophys. Res. Commun., 55, 1117-1124.

Tsuda, H, N. Inui and S. Takayama (1976) In vitro transformation of newborn hamster cells induced by sodium nitrite, Gann, 67, 165-173.

Tsuda, H. and K. Kato (1977) Chromosomal aberrations and morphological transformation in hamster embryonic cells treated with potassium dichromate in vitro, Mutat. Res., 46, 87-94. 